\title{
Kuşakların Nostalji Temalı Televizyon Reklamları Sonrası Tutumlarını İnceleyen Bir Araştırma*
}

\author{
Tuğsan KARADENİ*** Ayşe ŞAHİN***
}

\begin{abstract}
$\ddot{O} Z$
Tüketici davranışları içinde bulunulan çevre, yaşam tarzı, hayattan beklenti, gelir düzeyi ve eğitim durumu gibi birçok etmen sebebiyle farklllıklar gösterebilmektedir. Tüketicileri anlamanın ve kategorize edebilmenin bir yolu ise tüketicinin içinde bulunduğu yaş kuşağına göre karşılaştırmalar yapmaktır. Her kuşağın kendine has beklentileri, hayatı kavrayıs biçimi ve davranışs şekilleri olduğu düşünülmekte ve buna göre tüketiciler kategorize edilip tanımlanmaktadır. Pazarlama alanında sıklıkla başvurulan bu kategorizasyon araştırmalara yön vermekte, yaşanan bu gelişmeler, tüketicilerin daha derinlemesine araşstırlmasına ışık tutmaktadır. Illetişim sürecinde televizyon reklamlarında tüketicilere verilmek istenen mesajın etkinliğini artırmak amacıla birtakım metotlardan yararlanılmaktadır. Araştırmanın amacı; tüketicilerin izledikleri nostaljik televizyon reklamlarl sonrast, nostaljiye olan eğilimlerinin, reklam performans algısının, reklam sonrası duygularının, marka miras algılarının ve reklam sonrası tutumlarının farklılaşıp farklılaşmadığını yaş kuşaklarına göre ölçmektir. Bu amaçla 410 katılımclya kolayda örnekleme yöntemi kullanılarak ulaşılmış ve 43 sorudan oluşan anket formu yüz yüze görüşme yöntemi ve çevrimiçi katılım ile uygulanmıştır. Verilerin analizinde MANOVA'dan yararlanılmıştır. Tüketicilerin nostaljiye eğilimli olma durumunun yaş kuşaklarına göre farklılık gösterdiği belirlenmiştir. Nostaljik reklam performans algısı ve reklam sonrası tutumun da yaş kuşaklarına bağlı olarak farklılaştı̆̆ı ve bu algının en yüksek olduğu kuşağın 53-71 yaş aralı̆̆ında olan bebek patlaması kuşağında olduğu gözlemlenmiştir. Tüketicilerin yaş kuşaklarına göre reklam sonrası duyguları ve marka miras algısı arasında anlamlı bir farklılık saptanmamıștır.
\end{abstract}

Anahtar Kelimeler: Yaş Kuşakları, Nostalji Eğilimi, Marka Mirası, Duygular, Nostaljik Reklamlar

JEL Sinıflandırması: M30, M31, M37

\section{A Study Examining the Attitudes of Generations After Nostalgia-Themed Television Commercials}

\begin{abstract}
Consumer behavior differs due to many factors such as the environment, lifestyle, life expectancy, income level and education level. One way to understand and categorize consumers is to make comparisons according to their age generations. Each generation is thought to have their own expectations, way of understanding life and behaviors, and consumers are categorized and defined accordingly. This categorization, which is frequently used in the field of marketing, guides researches. These developments lead to a more in-depth investigation of consumers. In the communication process, a number of methods are used in order to increase the effectiveness of the message intended to be given to consumers in television advertisements. Purpose of the research is to measure whether consumers' tendency towards nostalgia, perception of advertising performance, post-advertisement emotions,
\end{abstract}

\footnotetext{
* Bu çalışma, "Farklı Yaş Kuşaklarındaki Tüketicilerin Nostalji Eğilimleri ve Nostalji Temalı Televizyon Reklamlarına Yönelik Tutumlarının İncelenmesi” başlıklı Doktora tezinden yararlanılarak hazırlanmıştır.

*** Dr. tugsan.karadeniz@outlook.com; ORCID Bilgisi: 0000-0001-7914-6886

**** Prof. Dr. Mersin Üniversitesi, İktisadi ve İdari Bilimler Fakültesi, İşletme Bölümü, asahin@mersin.edu.tr; ORCID Bilgisi: 0000-0001-7006-3072
} 
brand heritage perceptions and post-advertisement attitudes differ after watching nostalgic television commercials by age generations. For this purpose, 410 participants were reached by using the convenience sampling method and a questionnaire form consisting of 43 questions was applied with face-to-face interview and online participation methods. It has been determined that customers' proness to nostalgia differ depending on their age generations. Furthermore, it has been observed that the nostalgic advertising performance perception and post-advertisement attitude also differ depending on generations and the highest perception has been observed in the 53-71 age range which is also named as the baby-boomer generation. No significant difference was found between consumers' postadvertisement emotions and brand legacy perception depending on generations.

Key Words: Generations, Nostalgia Proneness, Brand Heritage, Emotions, Nostalgic Commercials

JEL Classification: M30, M31, M37

\section{GİRIŞ}

Tüketicilerin satın alma davranışları ve marka ilişkilerinin, sosyal kimliklerine katkıda bulunacağı yaygın olarak kabul görmektedir. Marka ilişkileri, marka toplulukları ve dikkate değer tüketim olayları da pazarda yer alan markalara ve sosyal etkileşimlerine verdikleri önemi ortaya koymaktadır. Söz konusu etkileşimlerin sosyal kimlikler tarafından yönlendirildiği kabul edilmektedir (Dimofte vd., 2015: 416). Kültür, bir toplumun kimliğini oluşturmaktadır. İletişimde davranış ve olayların yorumlanmasına yardımcı değerler, fikirler ve semboller dizisi olarak kabul edilmektedir. İnsan hayatı kültürle ilişkilendirilmiş ve reklamcılar için kültürel değerlerin yerini alacak ya da tamamlayabilecek tüketim kalıpları oluşturmak önem arz etmektedir. Reklamlarda kullanılan anlatım formları teknik anlamda benzer olsalar da mesajlar, izleyicilere kültürlerin etkisinde şekillenerek aktarılmaktadır (K. Aktuğlu ve Çolakoğlu, 2011: 10). Reklam ve kültür birbirleriyle iki farklı şekilde ilişkilendirilebilmektedir. İş kolu olarak düşünüldüğünde reklamcılık kültürün bir parçasıdır ve reklamların toplumun ortak kültürünün bir parçası olduğu ifade edilebilmektedir. Öte yandan ise reklamlarla uyandırılan mutluluk ve ifade edilen aile, sosyal sinıf, toplumsal cinsiyet, ulusal ve etnik kimlikler, din ve ırk gibi kategoriler de kültürün birer sembolleri olarak karşımıza çıkmaktadır (Gündel, 2010: 144).

Tüketicilerin kendilerini konfor alanında hissetmek için geçmişe dönme arzusunda oldukları bilinmektedir. Yaratıcılık ve tüketicilerin ilgisini çekmek söz konusu olduğunda, günlük hayatın var olan stresinden ve yeni çağın beraberinde getirdiği tempolu hayattan kaçış olarak görülen geçmişe dönme isteği, en etkili yollardan birisi olarak düşünülmektedir (Reisenwitz vd., 2004: 55). Bunu sağlamanın yolu ise nostalji duygusunu yaşamaktan geçmektedir.

Nostalji, Yunanca'da yer alan ve eve dönüşü ifade eden nostos ve acı çekmenin karş1lı̆̆ olan algos kelimelerinden türemiştir (Vignolles, 2014: 2-3). Holbrook (1993), nostaljiyi geçmişe duyulan özlem olarak ifade etmiş ve bunun yanında eski günlere ait eşyalara ve etkinliklere olan düşkünlük olarak tanımlamıştır. Bir çeşit tıbbi hastalık dahi olduğu düşünülen nostalji ilk başlarda yurt özlemine karşıllk olarak düşünülmüştür (Sedikides vd., 2008: 304). Pazarlama disiplini açısından nostalji, 1990'ların başlarından itibaren ilgi çekici bir konu olarak yer almaktadır (Merchant vd., 2016: 706). Nostaljinin hissedilebilmesi için uyaran 
oldukça önemlidir. Pazarlama açısından düşünüldügünde marka önemli bir uyaran olarak düşünülebilmektedir (Kessous ve Roux, 2010: 31). Retro modasının uluslararası bir hal aldığ günümüzde çoğu markanın da nostaljiden yararlandığ görülmektedir (Kessous ve Roux, 2010: 30). Reisenwitz vd. (2004), reklam verenlerle hedef pazar arasında kurulacak iletişimde doğru teknikleri kullanmanın zor olduğunu ve nostaljinin ise bu iletişimi sağlayabilmek için önemli bir araç olduğunu ifade etmiştir. Ancak birden fazla yaş kuşağının olduğu pazarda kuşaklara göre ihtiyaçlar ve davranışlar dikkate alınarak tüketici davranışlarının incelenmesi gerekmektedir (Williams ve Page, 2011: 1). Yaygın olarak kabul gören 5 farklı yaş kuşağından söz etmek mümkündür. Bunlar olgun kuşak, bebek patlaması kuşağı, $X$ kuşağı, $Y$ kuşağı ve $Z$ kuşağıdır. Her kuşağın kendine has beklentileri, tutumları ve davranışları söz konusudur.

Nostalji temalı televizyon reklamları düşünüldüğünde, kişiden kişiye farklılık gösterdiğine inanılan nostaljiye eğilim, izlenilen reklama ilişkin performans algısı, reklamın yarattığı duygular, markanın geçmiş performansını ve uzun ömürlüğünü ifade eden marka mirası kavramı ve reklam sonrası tutumun pazarda yer alan söz konusu yaş kuşakları açısından farklılaşıp farklılaşmadığı merak konusudur. Nostalji temasının pazarlama alanında henüz sınırlı sayıda araştırmacı tarafindan ele alındığ 1 görülmektedir. Bu noktadan hareketle, çalışmanın birinci bölümünde, nostalji eğilimi, nostaljik reklam performans algısı, reklam sonrası duygular, marka miras algıSı ve reklam sonrası tutum kavramları incelenmiştir. İkinci bölümde; araştırmanın amacı, yöntemi, hipotezleri sunulmuştur. Bulguların ardından ulaşılan sonuç ve öneriler yer almaktadır.

\section{NOSTALJİ EĞİLIMİ KAVRAMI}

Nostaljiye eğilimli olma geçmişe yönelik tutumla ilişkilendirilmekte ve (Hallegatte ve Marticotte, 2014: 84) bireylerin nostaljik duyguyu yaşama eğilimi olduğu kabul edilmektedir (Özhan ve Altuğ, 2017: 338). Yeni Oxford İngilizce Sözlüğünde (1988) ise, geçmişe karşı duygusal bir özlem veya özlemli bir sevgi olarak tanımlanmıştır. Holbrook (1993), nostalji eğiliminin bireyler arasında çeşidi ve şiddeti açısından farklılaştığını belirtmiştir. Marchegiani ve Phau (2010) ise, çalışmalarında bu farklılığın çeşitli faktörlere bağlı olduğunu ifade etmiş ve yaşı da bu faktörlerden biri olarak değerlendirmiştir. Son yirmi yıldır ise nostaljinin tüketiciler üzerindeki etkileri anlaşılmaya çalışılmaktadır (Muehling ve Pascal, 2011: 117). Holak vd. (2006), yaptıkları çalışmada nostaljiye eğilimin ölçülebilmesiyle nostaljik duyguları yaşama eğiliminde olan tüketicilerin duygusal yönden tespit edilmesini sağlayacağını ifade etmiştir.

\section{NOSTALJIKK REKLAM PERFORMANS ALGISI}

Pazarlamacıların nostaljinin düşünüldüğünden daha büyük çapta bir tüketici grubuna hitap edebileceğini keşfetmesiyle birlikte 1990'lı y1llarda nostalji temalı reklamlarda büyük bir patlama yaşanmıştır (Pascal vd. 2002: 40). Nostalji temalı bir TV reklamı düşünüldügünde, markanın hikayesi üzerinden empati yapmaya davet edilmekte, kurgusal bir geçmişi altın çağ şeklinde gösterebilmektedir. Reklamların tüketicilerin tüketim alışkanlıklarını olumlu yönde etkileyebilmesi de mümkündür (Morgül, 2017: 3). Reklamı bir süreç olarak gördügümüzde verilmek istenenin hedef 
kitle tarafından algılanabilmesi önemli bir koşuldur (Taşkıran ve Bolat, 2013: 52). Günümüzde TV reklamlarında nostalji temasından oldukça fazla yararlanıldığ görülmektedir. Nostalji temasının kullanıldığı reklamlarda dekor, eski dönemleri yansıtan kıyafet ve müzikler tüketiciyi etkileyebilmek ve eski özlem duyduğu günlere götürebilmek açısından önemlidir. Tüketiciler izledikleri reklam filmlerinde kendilerini ne düzeyde reklamın içinde hissedebilirse reklam performansı açısından o kadar başarılı sayılmaktadır.

\section{REKLAM SONRASI DUYGULAR}

Nörologlar günümüzde dikkat sürecinin büyük ölçüde bireyin bilinçli kontrolünün dışında gerçekleştiğini, bilişsel/rasyonel tepkiden ziyade duyguların dikkat çektiğini öne sürmektedir (Mehta ve Purvis, 2006: 50. Nicks ve Carriou (2016), duyguları içsel ya da dışsal durumlara karşı gösterilen soyut karşılıklar olarak tanımlamıştır. Bunun yanında öznel deneyimler, ifadeler, bedensel yanıt ve eylem eğilimi içerdiğini, genellikle de bilinçsiz yansımalar olarak karşımıza çıktığını belirtmiştir. Duyguların tüketici davranışları konularına eğilen araştırmacılar tarafından sıklıkla konu alındığı görülmektedir. Araştırma alanlarından bir tanesi de duyguların pazarlama aktiviteleri ve tüketimle olan ilişkilerini içermektedir (Holak ve Hevlana,1991: 328). Duygular, reklamların merkezinde yer almakta ve markalarla kurduğumuz ilişkilerin temelini oluşturmaktadır (Brandt, 2016: 3). Reklamın etkinliğini değerlendirirken duygular oldukça önemlidir. Reklam sevildiğinde, tüketicilerin markaya karşı olumlu tutum oluşturma olasılıkları da yükselmektedir (Anastasiei ve Chiosa, 2014: 48).

\section{MARKA MIRASI ALGISI}

Marka mirası geçmişte, günümüzde ve gelecekte firmanın görünümünü ifade etmektedir (Urde ve Greyser, 2015: 318). Tarihi bir marka, miras1 sayesinde kendisine değer kazandırabilmektedir. Marka kimliğinin bir boyutu olarak marka miras1, şirketin uzun ömürlülügünü temel almakta ve tüketicilerce yaşanan güvensizlik algısını kırmada önemli rol oynamaktadır (University of Bologna Business School, 2018). Bir mirasa sahip olmak kendi içinde değer yaratmamakla birlikte marka inşasının temelini oluşturmada önemli rol oynayabilmektedir (Hakala vd., 2011: 448). Bununla beraber reklam açısından düşünüldüğünde markalarca nostalji temasının kullanımı, dikkatli bir şekilde kullanılmadığı takdirde, marka mirasının yılların kolayca baltalayabilecek bir mayın tarlası olabilmektedir (Bussey, 2008: 11). Holak vd. (2008) ise, harici durumlarda pazarlamacıların hayali bir miras1 süsleyerek ya da anlatarak tüketicileri duygusal anlamda bağlamaya çalıştıklarını öne sürmüşlerdir. Her yaş kuşağının kendine has olarak kabul ettiği tarihleri, tarzları değerleri vb. farklılıkları vardır (Williams ve Page, 2011: 1). Pitt Catsouphes vd. (2009), içinde bulunulan ekonomik koşulların, yaşanılan tarihi olayların ve kültürel bazı değerlerin aynı yaş grubunu kapsayan bireylerin büyük bir kısmının dünyaya bakışını değiştirecek kadar yüksek potansiyelde olduğunu ifade etmiştir.

\section{REKLAM SONRASI TUTUM}

Reklamlar günümüzde yalnızca pazarlamanın değil, günlük yaşantımızın da bir parçası haline gelmiştir. İletişim araçlarının gelişmesinin beraberinde getirdiği modern reklamcılık ile mal ve hizmetlere olan talep artmış, ihtiyaçların 
yönlendirilmesi kolaylaşmış, ekonomik anlamda gelişmeler de hızlanmıştır. Ancak reklamlar tüketicileri olumlu yönde etkileyebildiği gibi olumsuz yönde de etkileyebilmektedir (Milli Eğitim Bakanlı̆̆1, 2012: 17-18). Reklamlar aracılı̆̆ıyla uyandırılan nostalji, reklamı yapılan ürün için hissedilen duyguların ve hislerin ortaya çıkarılmasında önemli bir rol oynayabilmektedir (Pascal vd., 2002: 41). Reklamların, satınalma açısından düşünüldüğünde tüketicide pozitif etkisinin olması beklenmektedir. Reklamın öncelikli rollerinden bir tanesi de markaya olan inancı ve tüketici farkındalığını arttırmaktır. Bunun yolu da, tüketicilere markanın varlığının hissettirilmesi ve sahip olduğu özelliklere tüketicilerin ikna olmasından geçmektedir (Deighton vd., 1994: 29). Firmalar, markalarını yeterince tanitamazlar ise, tüketicilerle bağ kurmakta zorlanacak, onları harekete geçirecek itici gücün ortaya çıkarılmasını sağlayamayacaklardır. Reklamların farkındalığı arttırmada ve iletişim kurmada bu denli önemli olduğu günümüz pazar koşullarında, tüketicilerin reklam sonrası tutumlarının belirlenmesinde de önemli rol oynadığı görülmektedir.

\section{ARAŞTIRMANIN AMACI}

Yapılan araştırma ile tüketicilerin yaş kuşaklarına bağlı olarak nostaljiye olan eğilimlerinin, nostaljik reklam performans algısının, reklamın yarattığ 1 duyguların, marka miras algısının ve reklam sonrası tutumlarının farklılık gösterip göstermediğinin açıklığa kavuşturulması amaçlanmaktadır.

\section{ARAŞTIRMANIN YÖNTEMİ}

Nostalji eğilimi, reklam performans algıs1, duygular, marka miras algisı ve reklam sonrası tutumun yaş kuşaklarına göre istatistiksel olarak anlamlı bir farklılık gösterip göstermediğini test etmek üzere yapılan araştırma nicel bir araştırmadır. Anket ile elde edilen birincil verilerden yararlanılmıştır. Mersin kent merkezinde yürütülen çalışmada, literatürde $\mathrm{X}, \mathrm{Y}, \mathrm{Z}$ ve Bebek patlaması dönemi olarak ifade edilen yaş kuşakları araştırma evrenini oluşturmaktadır. Çalışma kapsamında yararlanılan anket her kuşaktan katılımcıya uygulanmış ve çalışma yürütülmüştür. Toplamda 410 kişiden toplanan verilerle yürütülen çalışmada kolayda örnekleme yöntemi kullanılmıştır. Katılımcılara yüz yüze ve online olmak üzere iki farklı şekilde ulaştırılmış ve Nestle'nin nostalji temal1 100. Yıl reklamından yararlanılmıştır. Çalışmada kullanılan anket formu 3 bölümden ve toplamda 43 sorudan oluşmaktadır. Anketin bütünü incelendiğinde sorulardan 34 tanesi 5'li likert ölçeğinde 5'li likert derecelemesine göre hazırlanmış olup 5=Kesinlikle katılıyorum, 4=Kısmen katıliyorum, 3=Kararsızım, 2= Kismen katılmıyorum, 1=Kesinlikle katılmıyorum şeklinde kodlanmıştır. Duygu ifadeleri semantik farklılıklar ölçeği kullanılarak hazırlanmıştır.

Ortaya çıkan anketin oluşturulması sürecine Holbrook (1993)'ün nostalji eğilimi ölçeği, reklam performans algısını ölçmek üzere Debevec ve Iyer (1988)'in geliştirdikleri ölçekler kullanılmıştır. Faktör analizi sonucu reklam performans algısı ve reklama ilişkin ifadelerin aynı faktöre yüklenmesi sonucu bu iki ölçek nostaljik reklam performans algısı olarak isimlendirilerek analize dahil edilmiştir. Reklama ilişkin ifadeler, duygu tanımlamaları ve markaya ilişkin tanımlamalar için ise Merchant ve Rose (2013)'un geliştirdikleri ölçekten yararlanılmıştır. Reklam sonrası tutum değişkeni için ise Zehir ve arkadaşları (2011)'nın geliştirdiği ölçek 
kullanılmıştır. Araştırmanın verileri 0cak-Haziran 2017 tarihleri arasında toplanmıştır.

Anket katılımcılarının nostalji temalı televizyon reklamları hakkında fikir sahibi olabilmeleri ve tüketicilerde uyandırdığı duyguların tespit edilebilmesi amacıyla yararlanılacak reklam filmini belirlemek için nitel araştırma yönteminden yararlanılmıştır. Bu süreçte toplamda 14 tüketicinin yer aldığ 3 farklı odak grup görüşmesi gerçekleştirilmiş ve her kuşaktan tüketiciler görüşmeye dahil edilmiştir. Öncelikle çalışmanın amacı ve kapsamı hakkında bilgiler verilerek, nostalji temasının kullanıldığ 1 Jacobs, İş Bankası, Tikveşli, Arçelik ve Nestle 100. Yıl reklamı olmak üzere farklı sektörlere konu reklam filmleri izlettirilmiş ve verilen tepkiler gözlemlenerek notlar alınmıştır. Farklı hikayelerin anlatıldığı TV reklamlarında ortak nokta, tüketicileri geçmişe götürecek müzik, dekor, kostüm ve objelere yer verilmiş olmasıdır. "Her şey 120 yıl önce küçük bir kafede başlar" cümlesiyle başlayan Jacobs reklamında, bir kafe sahibinin yağmurdan kaçan bir kadını kafeye davet edip, kahve ikram ettiği hikaye anlatılmaktadır. Tikveşli reklamında ise yıllardır kavuşamayan bir çiftin ve Tikveşli'nin ön plana çıkardığ altın kaymağın hikayesi anlatılmaktadır. Nestle'nin 100. yıl reklamında ise, “ilk itiraf", "ilk heyecan" ve "ömür boyu sürsün dediğimiz günler oldu" gibi cümleler ile eski günleri gözler önüne seren ve tüketicilere Nestle markalı ürünlere ilişkin deneyimleri hatırlatılarak geçmişe götürdüğü görülmektedir. Görüşmeye katılan bireylere söz konusu nostalji temalı reklamlara yönelik tercihleri sorulmuş ve katılımcıların Tablo 1'de özetlendiği üzere tercihlerinden yola çıkılarak Youtube'dan erşilebilen Nestle'nin 100. Yıl Reklamı kullanılmıştır (https://www.youtube.com/watch?v=W9M932HuNDY).

Tablo 1. Ön Test Katılımcılarının Nostalji Temalı TV Reklam Tercihleri

\begin{tabular}{|l|c|}
\hline Reklamı yapılan nostalji temalı TV reklamı & Toplam tercih edilme sayısı \\
\hline İs Bankası & 3 \\
\hline Jacobs & 2 \\
\hline Tikveşli & 2 \\
\hline Nestle & 6 \\
\hline Arçelik & 1 \\
\hline
\end{tabular}

Odak grup görüşmelerinde reklamların katılımcılarda uyandırdığı duygular ve düşünceler sırasıyla sorulmuştur. Nestle reklamına ilişkin alınan yorumlarda, birliktelik duygusunu uyandıran, mutluluk veren, geçmişe götüren ve bunun yanında güven hissettiren etkileyici bir reklam olduğu ifade edilmiştir.

\section{ARAŞTIRMANIN HIPOTEZLERİ}

Nostalji eğilimi, bireylerin nostaljik duygu yaşama eğilimi olarak ifade edilmektedir (Özhan ve Altuğ, 2017: 338). Holbrook (1993), çalışmasında nostalji eğiliminin bireyler arasında farklılık gösterdiğini ifade etmiştir. Nostalji temelli ürünler, bu ürünlere ait reklamlar ve iletilecek mesajların özellikle yetişkin bireyleri hedef aldığı görülmektedir (Hevlana ve Holak, 1991: 327). Özhan ve Altuğ (2017), çalışmalarında yaşın nostalji eğilimi üzerindeki anlamlı etkisine değinmişlerdir. Yapılan araştırmalar nostaljiye eğilim ile yaş arasında pozitif bir ilişki olduğuna işaret etmektedir. Bu bilgiler ışığında kurulan hipotez; 
H1: Tüketicilerin nostalji eğilimi yaş kuşaklarına göre farklılık göstermektedir.

Ju vd. (2016), çalışmalarında gençlik ya da orta yaş dönemlerinde olan kişilerin geçmişi hatırlatacak reklamlar ile karşılaşması durumunda pozitif reaksiyonlar göstereceğini ve yetişkinler için bu reklamların büyük çoğunluk açısından uygun olduğunu ifade etmiştir. Holbrook (1993) ise, aynı yaş kuşaklarına yönelik hazırlanacak reklamların, yaşamlarında edindiği deneyimler açısından birbirine yakın olan bireylerde daha etkili olabileceğini ifade etmiştir. Bu bilgilerden yola çıkılarak reklamların tüketiciler üzerinde yarattı̆̆ arasında farklılık göstereceği düşünülmektedir. Kurulan hipotez;

H2: Tüketicilerin nostaljik reklam performans alg1s1 yaş kuşaklarına göre farkl111k göstermektedir.

Mehta ve Purvis (2006), reklamların etkin olabilmesi için öncelikle bazı duyguları harekete geçirmesinin gerekli olduğunu ifade etmiştir. Bazı kişilerde, nostalji hissedildiğinde duygu seline kapılmalarına kadar derinlemesine etkiler yaratabilmektedir (Holbrook, 1993: 254). Nostalji, objelere, kişilere ve edindikleri deneyimlere bağlı olarak bir zaman periyodunun yaratmış olduğu duygu ve ruh hali olduğundan yaş kuşaklarına bağlı olarak değiştiği iddia edilmektedir. Bu bilgilerden yola çıkılarak kurulan hipotez;

H3: Tüketicilerin reklam sonrası duyguları yaş kuşaklarına göre farklılık göstermektedir.

Marka miras algıs1, markanın uzun ömürlülüğü, öz değeri ve markaya özgü sembollerin bir arada ifadesi olarak karşımıza çıkmaktadır (Huber vd., 2013: 213). Markaya karşı edinilen deneyimlerin, markanın uzun ömürlülüğü ve dolayısıyla tüketicilerin markayla etkileşimlerinin uzunluğuna bağlı olarak yaş kuşaklarında farkl11ık gösterdiği öne sürülmektedir. Kurulan hipotez;

H4: Tüketicilerin marka miras algısı yaş kuşaklarına göre farklılık göstermektedir.

Hevlana ve Holak (1991), çalışmalarında nostalji temalı reklamların ve ürünlerin daha çok olgun tüketici gruplarını ve en fazla bebek patlaması dönemine ait tüketicileri hedef aldığını ifade etmiştir. Chou ve Singal (2017), nostaljik reklama yönelik duyarlılı̆̆ın geçmiş dönemlerde edinilen tecrübeler, yaşlanmaya olan etkisi ve tekrarlanma sıklığı gibi faktörlerden etkilendiğini ifade etmiştir. Aynı yaş kuşağında yer alan bireylerin reklam sonrası tutumlarının tecrübelere ve deneyimlere göre farklılaştığ 1 düşünülmektedir. Bu bilgilerden yola çıkılarak reklam sonrası tutumların yaş kuşaklarına göre farklılık gösterdiği düşünülmektedir. Kurulan hipotez;

H5: Tüketicilerin reklam sonrası tutumları yaş kuşaklarına göre farklılık göstermektedir.

\section{BULGULAR VE DEĞERLENDİRME}

Katılımcıların demografik özelliklerine ilişkin bilgileri incelediğimizde Tablo 2'de görüldüğü üzere çalışmaya katılan bireylerin \%54,1'i kadın, \%45,9'u ise erkektir. Kuşaklar açısından incelendiğinde ise katılımcıların \%29'unu X kuşağı, \% 
29'unu Y kuşağı, \% 24,1'ini Z kuşağı ve \% 17,8'ini bebek patlaması kuşağ oluşturmaktadır.

Tablo 2. Örneklemin Demografik Özellikleri

\begin{tabular}{|l|l|c|c|}
\hline Değişkenler & & $\mathbf{n}$ & \% \\
\hline Cinsiyet & Kadın & 222 & 54,1 \\
\hline & Erkek & 188 & 45,9 \\
\hline Yaş & 22 ve altı (Z kuşağı) & 99 & 24,1 \\
\hline & $23-37$ (Y kuşağı) & 119 & 29,0 \\
\hline & $38-52$ (X kuşağı) & 119 & 29,0 \\
\hline & $53-71$ (Bebek patlaması) & 73 & 17,8 \\
\hline & & $n=410$ & \\
\hline
\end{tabular}

Araştırma kapsamında yapılan analizlerin yorumlanmasına geçmeden önce ölçeklerin geçerlilik ve güvenilirliği test edilmiştir. Anketi oluşturan ölçekler ayrı ayrı güvenilirlik analizine tabi tutulmuştur. İç tutarlılığın tespit edilmesi amacıyla yaygın olarak Cronbach's Alpha katsayıları kullanılmaktadır. Bu katsayıların ideal olarak 0,7 'nin üzerinde olması istenmektedir. Tablo 3 'de görüldüğü üzere Cronbach's Alpha değerleri bu değerin üzerindedir.

Tablo 3. Cronbach's Alpha Değerleri

\begin{tabular}{|l|c|c|}
\hline Değișken & İfade sayısı & Cronbach Alpha \\
\hline Nostalji Ĕ́gilimi & 4 & 0,795 \\
\hline Nostaljk Reklam Performans Alglsı & 13 & 0,937 \\
\hline Reklam Sonrası Duygular & 7 & 0,803 \\
\hline Marka Miras Alglsı & 11 & 0,910 \\
\hline Reklam Sonrası Tutum & 6 & 0,932 \\
\hline
\end{tabular}

Tablo 4. Kaiser- Meyer- Olkin ve Bartlett's Testi

\begin{tabular}{|c|c|c|}
\hline \multirow{4}{*}{$\begin{array}{l}\text { KMO Test } \\
\text { Bartlett's Test }\end{array}$} & & ,928 \\
\hline & $\chi^{2}$ & 11145,918 \\
\hline & $\mathrm{Df}$ & 820 \\
\hline & Sig. & ,000 \\
\hline
\end{tabular}

Değişken setinin faktör analizine uygunluğunu test etmek amaciyla ise Kaiser-Meyer-Olkin skoru kullanılmaktadır. Veri analizi yapmak için uygun olan değerin 0,50'nin üzerinde olması beklenmektedir. Bu değer 0,80'in üzerinde ise oldukça iyi anlamına gelmektedir. Bartlett küresellik testinin sonucu ise modelin uygunluğu için önemlidir. Modelin anlamlılığının kabul edilebilmesi için $p<0,05$ koşulunu sağlaması gerekmektedir (Frohlich ve Westbrook, 2001: 189). Tablo 4'de görüleceği üzere KMO değeri 0,928 olarak hesaplanmıştır. Bu değer oldukça iyi olarak ifade edilmektedir. Yapılan faktör analizi sonucunda ifadelerin 5 faktör altında toplandığ 1 görülmektedir.

Araştırma kapsamında nostalji eğiliminin yaş kuşakları arasında farklılık gösterip göstermediğini test etmek amacıyla MANOVA testi sonuçları Tablo 5'de görülmektedir. Nostalji eğilimi düzeylerinin katılımcıların yaş kuşakları arasında 
anlamlı farklılıklar gösterdiği tespit edilmiştir. Hesaplanan farklılık istatistiksel olarak anlamlıdır $(\mathrm{p}<0,05)$. Games Howel testine göre $Z$ kuşağı ile $X$ ve Bebek patlaması kuşakları arasında nostalji eğilimi düzeyi açısından istatistiksel olarak anlamlı farklılıklar olduğu görülmektedir. $\mathrm{Bu}$ sonuçlara göre $\mathrm{H}_{1}$ hipotezi desteklenmiştir.

Tablo 5. Kuşaklara Göre Nostalji Eğiliminin Farklılı̆̆ının MANOVA Testi Sonuçları

\begin{tabular}{llll}
\hline Yaş & $\mathbf{n}$ & Ortalama & p \\
\hline 22 ve altı (Z kuşağı) & 99 & 3,72 & 0,006 \\
23-37 (Y kuşağı) & 119 & 4,67 \\
& & 4,33 \\
$\mathbf{3 8 - 5 2}$ (X kuşağı) & 119 & 3,94 \\
$\mathbf{5 3 - 7 1}$ (Bebek batlaması) & 73 & & \\
Toplam & 410 & 3,94
\end{tabular}

Post-Hoc Testi (Games Howel)

\begin{tabular}{llll}
\hline Kuşaklar & & Ortalamalar farkı & p \\
\hline 22 ve altı (Z kuşağı) & $23-37$ &, 0458 &, 986 \\
& $38-52$ &,$- 4353(*)$ &, 007
\end{tabular}

Tablo 5 Devamı:

\begin{tabular}{llll} 
& $53-71$ &,$- 6168(*)$ &, 000 \\
$\mathbf{2 3 - 3 7}$ (Y kuşağı) & 22 ve altı &,- 0458 &, 986 \\
& $38-52$ &,$- 4811(*)$ &, 000 \\
& $53-71$ &,$- 6626(*)$ &, 007 \\
$\mathbf{3 8 - 5 2}$ (X kuşağı) & 22 ve altı &, $4353(*)$ &, 446 \\
& $23-37$ &, $4811(*)$ &, 000 \\
$\mathbf{5 3 - 7 1}$ (Bebek patlaması) & $53-71$ &,- 1815 &, 000 \\
& 22 ve altı &, $6168(*)$ &, $6626(*)$ \\
\hline
\end{tabular}

Nostaljik reklam performans algısının yaş kuşakları arasında farklı1ık gösterip göstermediğini test emek amacıyla MANOVA testi yapılmıştır. Hesaplanan farklı1ık istatistiksel olarak anlamlıdır $(\mathrm{p}<0,05)$. Yaş kuşaklarının nostaljik reklam performans algıları arasında anlamlı farklılıklar bulunmaktadır. $\mathrm{H}_{2}$ hipotezi desteklenmiştir. Games Howel Testi sonucu ise Z kuşağı ile X ve Bebek patlaması kuşağı arasında nostaljik reklam performans algısı açısından anlamlı farklılıklar olduğunu göstermektedir. 
Tablo 6: Kuşaklara Göre Nostaljik Reklam Performans Algısının Farklılı̆̆ının

MANOVA Testi Sonuçları

\begin{tabular}{llll}
\hline Yaş & $\mathbf{n}$ & Ortalama & p \\
\hline 22 ve altı (Z kuşağı) & 99 & 3,40 & \\
$\mathbf{2 3 - 3 7}$ (Y kuşağı) & 119 & 3,70 & \\
$\mathbf{3 8 - 5 2}$ (X kuşağı) & 119 & 3,75 & \\
$\mathbf{5 3 - 7 1}$ (Bebek patlaması) & 73 & 3,95 & \\
Toplam & 410 & 3,69 & \\
\hline
\end{tabular}

Post-Hoc Testi (Games Howel)

\begin{tabular}{lllc}
\hline Kuşaklar & & Ortalamalar farkı & p \\
\hline 22 ve altı (Z kuşağı) & $23-37$ &,- 3003 &, 094 \\
& $38-52$ &,$- 3508\left(^{*}\right)$ &, 037 \\
& $53-71$ &,$- 5504\left(^{*}\right)$ &, 001
\end{tabular}

Tablo 6 Devamı:

\begin{tabular}{|c|c|c|c|}
\hline \multirow[t]{3}{*}{ 23-37 (Y kușağı) } & 22 ve alt & ,3003 & ,094 \\
\hline & $38-52$ &,- 0504 &, 970 \\
\hline & $53-71$ &,- 2501 &, 181 \\
\hline \multirow[t]{3}{*}{ 38-52 (X kuşağı) } & 22 ve alt 1 & ,3508(*) & ,037 \\
\hline & $23-37$ &, 0504 & ,970 \\
\hline & $53-71$ &,- 1996 &, 379 \\
\hline \multirow[t]{3}{*}{ 53-71 (Bebek patlaması) } & 22 ve alt 1 &, $5504(*)$ & ,001 \\
\hline & $23-37$ &, 2501 &, 181 \\
\hline & $38-52$ & ,1996 &, 379 \\
\hline \multicolumn{4}{|c|}{$\begin{array}{l}\text { Reklam sonrası duyguların yaş kuşaklarına göre farklılı̆̆ının istatistiksel } \\
\text { açıdan anlamlı olup olmadığını test etmek amacıyla MANOVA Testi yapılmıştır. } \\
\text { Tablo 7'de görüleceği üzere p değeri } 0,232 \text { olarak hesaplanmıştır. Reklam sonrası } \\
\text { duygular ile kuşaklar arasında anlamlı bir farklılık görülmediği sonucuna } \\
\text { ulaşılmaktadır (p>0,05). } \mathrm{H}_{3} \text { hipotezi desteklenmemiştir. } \\
\text { Tablo 7: Kuşaklara Göre Reklam Sonrası Duyguların Farklılığının MANOVA Testi }\end{array}$} \\
\hline Yaş & $\mathbf{n}$ & Ortalama & $\mathbf{p}$ \\
\hline 22 ve altı ( $Z$ kuşağı) & 99 & 7,5758 & 0,232 \\
\hline 23-37 (Y kuşağı) & 119 & 7,4454 & \\
\hline 38-52 (X kuşağı) & 119 & 7,4370 & \\
\hline 53-71 (Bebek patlaması) & 73 & 7,9349 & \\
\hline Toplam & 410 & 7,5616 & \\
\hline
\end{tabular}


Marka miras algısının yaş kuşakları arasında farklı olup olmadığının test edilmesi amacıyla MANOVA testi yapılmıştır. Yaş kuşaklarına göre marka miras algısında istatistiksel açıdan anlamlı farklılık bulunmamaktadır ( $>>0,05) . \mathrm{H}_{4}$ hipotezi desteklenmemiştir.

Tablo 8: Kuşaklara Göre Marka Miras Algısının Farklılığının MANOVA Testi

\begin{tabular}{lcll}
\hline Yaş & n & Ortalama & p \\
\hline 22 ve altı (Z kuşağı) & 99 & 4,2525 & 0,052 \\
$\mathbf{2 3 - 3 7}$ (Y kuşağı) & 119 & 4,1786 & \\
$\mathbf{3 8 - 5 2}$ (X kuşağı) & 119 & 4,4013 & \\
$\mathbf{5 3 - 7 1}$ (Bebek patlaması) & 73 & 4,3236 & \\
Toplam & 410 & 4,2869 & \\
\hline
\end{tabular}

1Yaş kuşakları açısından reklam sonrası tutumun farklılık gösterip göstermediğini test etmek amacıyla yapılan MANOVA Testi sonucuna göre hesaplana p değeri, yaş kuşakları açısından istatistiksel olarak anlamlı bir farklılık göstermektedir $(\mathrm{p}<0,05)$. Games Howel Testi sonucunda ise bebek patlaması kuşağı ile X,Y,Z kuşakları arasında reklam sonrası tutum açısından anlamlı farklılık bulunmaktadır. $\mathrm{H}_{5}$ hipotezi desteklenmiştir.

Tablo 9: Kuşaklara Göre Reklam Sonrası Tutumun Farklılığının MANOVA Testi

\begin{tabular}{llll}
\hline Yaş & $\mathbf{n}$ & Ortalama & p \\
\hline 22 ve altı (Z kuşağı) & 99 & 4,1582 & 0,001 \\
$\mathbf{2 3 - 3 7}$ (Y kuşağı) & 119 & 4,2255 & \\
$\mathbf{3 8 - 5 2}$ (X kuşağı) & 119 & 4,3669 & \\
$\mathbf{5 3 - 7 1}$ (Bebek patlaması) & 73 & 4,6279 & \\
& 410 & 4,3200 & \\
\hline
\end{tabular}

Post-Hoc Testi (Games Howel)

\begin{tabular}{llll}
\hline Kuşaklar & & Ortalamalar farkı & p \\
\hline 22 ve altı (Z kuşağı) & $23-37$ &,- 0672 &, 934 \\
& $38-52$ &,- 2087 &, 275 \\
& $53-71$ &,$- 4696\left(^{*}\right)$ &, 000 \\
$\mathbf{2 3 - 3 7}($ Y kuşağı) & 22 ve altı &, 0672 &, 934 \\
& $38-52$ &,- 1415 &, 522
\end{tabular}

Tablo 9 Devamı:

$\begin{array}{llll} & 53-71 & -, 4024\left(^{*}\right) & , 000 \\ \text { 38-52 (X kuşağı) } & 22 \text { ve altı } & , 2087 & , 522 \\ & 23-37 & , 1415 & , 041 \\ & 53-71 & -, 2609\left(^{*}\right) & ,\end{array}$


Tablo 10: Araştırma Hipotezlerinin Genel Değerlendirilmesi

\begin{tabular}{|l|l|}
\hline Araştırma Hipotezleri & \multicolumn{1}{c|}{ Sonuç } \\
\hline $\mathbf{H}_{1}:$ Tüketicilerin nostalji eğilimi yaş kuşaklarına göre farklılık göstermektedir & DESTEKLENDİ \\
\hline $\begin{array}{l}\mathbf{H}_{2}: \text { Tüketicilerin nostaljik reklam performans algısı yaş kuşaklarına göre farklılık } \\
\text { göstermektedir. }\end{array}$ & DESTEKLENDİ \\
\hline $\mathbf{H}_{3}:$ Tüketicilerin reklam sonrası duyguları yaş kuşaklarına göre farklılık göstermektedir. & DESTEKLENMEDİ \\
\hline $\mathbf{H}_{4}:$ Tüketicilerin marka miras algısı yaş kuşaklarına göre farklılık göstermektedir. & DESTEKLENMEDİ \\
\hline $\mathbf{H}_{5}:$ Tüketicilerin reklam sonrası tutumları yaş kuşaklarına göre farklılık göstermektedir. & DESTEKLENDİ \\
\hline
\end{tabular}

Genel bir değerlendirme yapıldığında yaş kuşaklarına bağlı olarak sadece marka miras algısının ve reklam sonrası duyguların yaş kuşaklarına göre anlamlı farklılıklar içermediği ortaya çıkmıştır.

\section{SONUÇ VE ÖNERILER}

Günümüzde pazarlamacıların hedef aldıkları kitlelere doğru mesajları doğru kanallardan ulaştırmayı amaçladığı görülmektedir. Reklamlarda nostalji temasının kullanılması reklam verenler açısından önemli bir alternatiftir. Son yıllarda popüler hale gelen nostalji temasının izleyenleri geçmişe götürme açısından başarılı ve dikkat çeken bir konsept olduğu düşünülmektedir. Pazarda yer alan her yaş grubunun kendine has beklentileri ve kendi içinde yaygın sayılabilecek davranış ve tutumları olduğu bilinmektedir. Yaş kuşakları arasında bu denli farklılıkların bulunması, pazarlamacıların stratejilerinde doğru kararlar almasını kolaylaştırdığ varsayımından yola çıkılarak Mersin ilinde yaşayan $\mathrm{X}, \mathrm{Y}, \mathrm{Z}$ ve Bebek patlaması kuşağında yer alan tüketicilerin nostalji eğilimi, nostaljik reklam performans algısı, reklam sonrası duygular, marka miras algisı ve reklam sonrası tutumlarının farklılık gösterip göstermediğini ortaya koymak hedeflenmiştir. Yapılan araştırma sonucunda nostaljik duygu yaşama eğilimi olarak kabul edilen nostalji eğilimi düzeyinin yaş kuşakları arasında farklılık gösterdiği ortaya çıkmıştır. Nostaljik reklam performans algısının da yaş kuşaklarına göre farklılaştığı araştırmanın bir diğer sonucu olarak karşımıza çıkmaktadır. Bu algının en yükssek olduğu kuşağın bebek patlaması kuşağ1 olduğu tespit edilmiştir. Reklam sonrası duyguların ve marka miras algısının da araştırıldığı çalışma sonucunda yaş kuşakları arasında anlamlı bir farklılığın olmadığı saptanmıştır. Reklam sonrası tutum ise, kuşaklar arasında istatistiksel olarak anlamlı düzeyde farklılık göstermekte ve en büyük farklılık diğer kuşaklara kıyasla 53-71 yaş aralığında yer alan bebek patlaması kuşağında görülmektedir.

Yaş temelli kuşaklara yönelik tüketim davranışı araştırmalarının günümüz pazarlama çalışmalarında üzerinde önemle durulan konulardan biri olduğu görülmektedir. Tüketici gruplarının farklılaştığı pazarda kuşakların iyi analiz edilip beklentilerinin anlaşılması önemlidir. Nostalji eğiliminin diğer yaş gruplarına oranla bebek patlaması ve $\mathrm{X}$ kuşaklarında yüksek olması sebebiyle, nostalji temalı televizyon reklamlarının söz konusu kuşaklara yönelik olarak hazırlanması yerinde olacaktır. Reklam sonrası tutumun ve reklam performans algısının ileriki yaşlarda 
yer alan tüketicileri daha fazla etkilemesi reklam verenlerin üzerine düşünmesi gereken konulardan biridir.

Reklam yapımcılarının reklamlarda nostalji temasını kullanırken, sosyal sorumluluk ve ahlaki kurallara dikkat etmeleri gerekmektedir. Uyandırdığ duyguların özellikle 65+ yaş kuşağındaki tüketicilerin marka tercihinde önemli rol oynaması sebebiyle günümüzde sıklıkla yararlanılan nostalji temasıyla hedef kitleye doğru bilgiler verilmelidir. Gerçeklerin dışına çıkılarak, tüketicilere yanlış ve abartılı bilgiler verilmemelidir.

Gelecek çalışmalarda, farklı kategorilerde ürün çeşitleri ve nostalji temalı ambalajlar üzerine araştırmalar yapılarak, bu ambalajların tüketici davranışları üzerindeki etkileri incelenebilir. Araştırma Mersin kent merkezinde yaşayan farklı yaş kuşaklarındaki tüketicileri üzerinde yapılmış olup, gelecekte ülkemizde farklı illerde de yapılarak karşılaştırmalar gerçekleştirilebilir.

\section{Araştırma ve Yayın Etiği Beyanı}

Makalenin tüm süreçlerinde Yönetim ve Ekonomi Dergisi'nin araştırma ve yayın etiği ilkelerine uygun olarak hareket edilmiştir.

Yazarların Makaleye Katkı Oranları

Yazarlar çalışmaya eşit oranda katkı sağlamıştır.

\section{Çıkar Beyanı}

Yazarın herhangi bir kişi ya da kuruluş ile çıkar çatışması yoktur.

\section{KAYNAKÇA}

Anastasiei, B. ve Chiosa, R. (2014). Emotional response to advertising. Euro Economica, 2(33), 43-49.

Brandt, David. (2016). What's next: Emotions give a lift to advertising. Retrieved April 15, 2018, from http://www.nielsen.com/us/en/insights/reports/2016/whats-next-emotions-give-a-lift-toadvertising.html.

Chou, H.Y. ve Singhal, D. (2017). Nostalgia advertising and young Indian consumers: The power of old songs. Asia Pacific Management Review, 22, 136-145.

Debevec, K., ve Iyer, E. (1988). Self-referencing as a mediator of the effectiveness of sexrole portrayals in advertising. Psychology and Marketing, 5(1), 71-84.

Deighton, J., Henderson, C.M. ve Neslin, S. A. (1994). The effects of Advertising on brand switching and repeat purchasing. Journal of Marketing Research, 31, 28-43.

Dimofte, C. V., Goodstein, R. C. ve Brumbaugh, A.M. (2015). A social identity perspective on aspirational advertising: Implicit threats to collective self-esteem and strategies to overcome them. Journal of Consumer Psychology, 25(3), 416-430.

Filmpark (Yapımc1) ve Karataş, B. (Yönetmen). (2015). Nestle 100. Yll. [Reklam Filmi] https://www.youtube.com/watch?v=W9M932HuNDY

Frohlich, M. T. ve Westbrook, R. (2001). Arcs of integration: an international study of supply chain strategies. Journal of Operations Management, 19, 185-200.

Gündel, N. (2010). Kültürel küreselleşmenin reklam mesajlarına yansımaları. Doktora Tezi, Selçuk Üniversitesi Sosyal Bilimler Enstitüsü Halkla İlişkiler ve Tanıtım Ana bilim Dalı, Konya.

Hevlana, W.J. ve Holak, S.L. (1991). "The good old days": Observations on nostalgia and its role in consumer behavior. Advances in Consumer Research, 18, 323-329.

Hakala, U., Latti, S. ve Sandberg, B. (2011). Operationalising brand heritage and cultural heritage. Journal of Product \& Brand Management, 20(6), 447-456.

Holak, Susan L, Havlena William J. ve Matveev, Alexei V. (2006). Exploring nostalgia in Russia: Testing the index of nostalgia-proneness. European Advances in Consumer Research, 7, 195200. 
Holak, S.L., A.V. Matveev, and W.J. Havlena. 2008. Nostalgia in post-socialist Russia: Exploring applications to advertising strategy. Journal of Business Research 61, no. 2: 1728.

Holbrook, M.B. (1993). Nostalgia and consumption preferences: Some emerging patterns of consumer tastes. Journal of Consumer Research, 20, 245-256.

Huber, F., Meyer, F., Vogel, J., Weihrauch, A. ve Hamprecht, J. (2013). Endorser age and stereotypes: Consequences on brand age. Journal of Business Research, 66, 207-215.

Ju, I., Choi, Y., Morris, J., Liao, H.W. ve Bluck, S. (2016). Creating nostalgic advertising based on the reminiscence bump: Diachronic relevance and purchase intent. Applied Cognitive Psychology, Appl. Cognit. Psychol, 30, 465-471.

Karpat, A., I. ve Çolakoğlu, B.E. (2011). Kültürün reklam üzerindeki etkisi: Reklam biçimlerinin kültür tarafindan belirlenmesi. Yeni düşünceler, 6, 9-23.

Kessous, A., ve Roux, E. (2010). Brand considered as "nostalgic": Consequences on attitudes and consumer-brand relationship. Recherche et Applications en Marketing, 25(3), 29-55.

Marchegiani, C. ve Phau, I. (2010). The value of historical nostalgia for marketing management. Marketing Intelligence \& Planning, 29(2), 108-122.

Mehta, A. ve Purvis, S.C. (2006). Reconsidering recall and emotion in advertising. Journal of Advertising Research, March, 49-56.

Merchant, A. ve Rose, GM. (2013). Effects of advertising- evoked vicarious nostalgia on brand heritage. Journal of Business Research. 66, 2619-2625.

Merchant, A., Ford, J.B, Dianoux, C. ve Herrmann, J.L. (2016). Development and validation of an emic scale to measure ad-evoked nostalgia in France. International Journal of Advertising, 35(4), 706-729.

Milli Eğitim Bakanlığı (MEB) (2012). Reklamın Etkileri, Aile ve Tüketici Hizmetleri Birimi, Ankara.

Muehling, D.D. ve Pascal, V.J. (2011). Empirical investigation of the differential effects of personal, historical, and non-nostalgic advertising on consumer responses. Journal of Advertising, 40(2), 107-122.

Özhan, Ş. ve Altuğ, N. (2017). Demografik değişkenler açısından nostalji eğilimini belirlemeye yönelik bir araştırma. Trakya Üniversitesi Sosyal Bilimler Dergisi, 19(1), 337-350.

Pascal, V. J., Sprott, D. E. ve Muehling, D. D. (2002, Spring). The influence of evoked nostalgia on consumers' responses to advertising: An exploratory study. Journal of Current Issues and Research in Advertising, 24(1), 39-49.

Pitt Catsouphes, M., Matz-Costa, C. ve Besen, E. (2009). Age \& generations: Understanding experiences at the workplace. The Sloan Center on Aging \& Work at Boston College, Research Highlight, 6, 1-43.

Reisenwitz, T.H., Iyer, R. ve Cutler, B. (2004). Nostalgia advertising and the influence of nostalgia proneness. The Marketing Management Journal, 14(2), 55-66. Reklamın etkileri. (2012). Ankara: T.C. Milli Eğitim Bakanlığı.

Sedikides, C., Wildschut, T., Arndt, J. ve Routledge, C. (2008), Nostalgia: Past, present, and future. Current Directions in Psychological Science, 17(5), 304-307.

The New Oxford Dictionary of English. (Ed.) (1998). Oxford, UK: Oxford University Press. Vignolles, A. ve Pichon, P.E. (2014). A taste of nostalgia: Links between nostalgia and food consumption. Qualitative Market research, 1-18.

Williams, K.C. ve Page, R.A (2011). Marketing to the generations. Journal of behavioral Studies in Business, 3, 1-17.

Zehir, C., Şahin, A., Kitapçı, H. ve Özşahin, M. (2011). The effect of brand communication and service quality in building brand loyalty through brand trust. Procedia social and behavioral sciences, 24,1218-1231.

\section{SUMMARY}

Being a social entity brings people into a communication process within the environment they live in. In the communication process, the message must be sent to the people through the right channels and at the right time. Television commercials, which are considered important in today's marketing activities and 
make it possible to reach many people at the same time, are frequently used as one of the communication tools. Television advertisements are categorized in different ways in terms of content. The use of television commercials, which uses the theme of nostalgia that evokes emotions by revealing the longing for the past, began to spread after the 1990s and focused on their effects on consumers. Within the scope of the research, the nostalgia tendencies and attitudes of consumers of different age generations towards nostalgia-themed television commercials were analyzed with the selected commercial film. Questionnaire has been implemented to 410 people and relations have been analyzed via structural equation modeling respecting to nostalgia proneness, nostalgic commercial performance perception, postcommercial emotions., brand heritage perception and post-commercial attitude. Quantitative research method has been used in line as the purpose of the research. In the researches made on age generations, it has been observed that the level of nostalgia tendency, which is expressed as a tendency to experience nostalgic feelings, showed differences between age generations. It has been observed that the nostalgia tendency of people in the baby-boomer and X generations was higher than other age generations. Commercials evoke emotions by leaving some effects on the viewers. It was observed that the post-commercial emotions regarding the commercial watched showed no significant differences by generations. It has been concluded that the level of nostalgia tendency of people had a positive effect on the perception of nostalgic commercial performance. In this study which also searched for the effect of nostalgia tendency on brand heritage, it was seen that nostalgia tendency, which is a dimension of brand identity. also had a positive effect on brand heritage perception, it has been found out that the brand heritage perception had a positive effect on the post-advertisement attitude. In addition, the perception of brand heritage, the perception of advertising performance and the effects of the mediation of emotions have been searched. And it has been observed that the perception of advertising performance of consumers has positively affected post-advertising attitude through brand heritage perception. 